\title{
MODEL PEMBANGUNAN DESA TERPADU INOVATIF DI JAWA TENGAH
}

\section{INNOVATIVE MODEL OF INTEGRATED RURAL DEVELOPMENT IN CENTRAL JAVA}

\author{
Suharyanto \& Arif Sofianto \\ Badan Penelitian dan Pengembangan Provinsi Jawa Tengah \\ E-mail: areef_sofiant@yahoo.com \\ Jalan Imam Bonjol No. 190, Semarang \\ Diterima: 6 November 2012; direvisi: 20 November 2012; disetujui: 10 Desember 2012
}

\begin{abstract}
Abstrak
Tujuan dari penelitian ini adalah: 1). Membangun model pembangunan desa yang berjalan secara terpadu dan inovatif;2). Mengetahui prasyarat yang diperlukan dalam pembangunan desa yang terpadu dan mengedepankan inovasi; dan 3). Mendeskipsikan peran masing-masing pihak dalam mewujudkan pembangunan desa yang terpadu dan mengedepankan inovasi. Penelitian dilakukan di 3 desa yang memiliki keunggulan dalam pembangunan, yaitu: 1). Mlatiharjo Kecamatan Gajah Kabupaten Demak; 2). Samiran, Kecamatan Selo Kabupaten Boyolali; dan 3). Jatiroyo, Kecamatan Jatipuro Kabupaten Karanganyar. Penelitian ini menggunakan pendekatan deskriptif kualitatif . Kesimpulan dari penelitian ini adalah: 1). Model pembangunan desa terpadu inovatif merupakan proses yang mengutamakan sinkronisasi antarsektor dan antarpelaku serta mengedepankan inovasi dalam berbagai bidang sebagai tekniknya; 2). Prasyarat pembangunan desa terpadu inovatif adalah: teridentifikasinya potensi sumberdaya dan arah pembangunan serta menumbuhkan inovasi sebagai teknik pembangunan; dan 3). Peranan yang perlu dilakukan oleh masing-masing pihak terkait dalam pembangunan desa adalah a). Pemerintah, pemerintah provinsi, pemerintah kabupaten harus konsisten dan terarah dalam merumuskan arah kebijakan; b). Pemerintah desa melakukan identifikasi potensi dan menentukan arah kebijakan; c). Masyarakat desa dan lembaga kemasyarakatan desa berpartisipasi dan melakukan pengawasan; d). Akademisi memberikan masukan iptek dan pendampingan; dan e). Pelaku usaha melakukan investasi dan kerjasama.
\end{abstract}

Kata kunci: model, desa, pembangunan terpadu, inovasi

\begin{abstract}
The purpose of this study was to: 1). Build a model of rural development which runs in an integrated manner and promote innovation; 2). Understanding the prerequisites required in the integrated rural development and promote innovation; and 3). Describe the role of each party in creating an integrated rural development and promote innovation. The study was conducted in 3 villages categorized as having excellence in the governance of development, namely: 1). Mlatiharjo, Gajah Sub-District, Demak Regency; 2). Samiran, Selo Sub-District, Boyolali Regency; dan 3.) Jatiroyo, Jatipuro Sub-District, Karanganyar Regency. The research method used is descriptive qualitative. The conclusion of this study were: 1). Model of integrated and innovatiive development is performed with emphasis on synchronization between sectors and stakeholders, encouraging HR utilize local resources to make innovations in rural development;2). Prerequisites innovative integrated rural development is identification of potential resources and direction of development, the implementation of appropriate resource management and innovation as the construction techniques; 3). The role needs to be done by the respective parties involved in rural development are: a). government, provincial governments, district governments should be consistent and focused in formulating policy directions; $b$ ). village government to identify potential and determine the direction of policy, build coordination and synchronization as well as facilitating and promoting community empowerment; $c$ ). villagers and village community organizations to participate and conduct supervision; d). provide feedback science and technology academics and mentoring; and e). business investment and cooperation
\end{abstract}

Keywords: model, rural, integrated development, innovation

\section{PENDAHULUAN}

Desa merupakan wilayah yang menyita perhatian banyak pihak, berbagai problem bisa dikaji dan mendesak untuk diselesaikan. Kekuatan ekonomi desa tidak berdaya terhadap mekanisme pasar, dan desa selalu berada pada ketidakberdayaan dan ketidakseimbangan hubungan dengan kota. Desa-desa di Indonesia umumnya menghadapi ancaman keterbelakangan dan ketidakadilan dalam pembangunan. Secara alamiah ada semacam dilema, yaitu kemiskinan dan pengetahuan yang rendah 
menyebabkan pemanfaatan yang kelewat batas atas sumberdaya alam untuk bertahan hidup, akan tetapi di sisi lain banyak sumberdaya yang ternyata belum dimanfaatkan secara optimal seperti sinar matahari, air, angin, tanaman, ikan, ternak dan tenaga manusia (Daldjoeni \& Suyitno, 2004:126). Hal senada diungkapkan oleh Rustadi, bahwa di sektor masyarakat tradisional banyak sekali sumberdaya alam yang belum dikembangkan secara optimal disebabkan karena masih terbelakangnya masyarakat tersebut, kekurangan modal, sehingga tingkat produktifitas rendah dan berimplikasi terhadap tingkat pendapatan yang rendah (Ernan Rustadi, 2009:142). Keterbatasan pengetahuan dan modal menjadi faktor yang menghambat pembangunan desa.

Walapun pembangunan terhadap desa sudah cukup lama akan tetapi sampai saat ini masih terdapat persoalan yang dihadapi desa dan membutuhkan penyelesaian segera. Program-program yang ada lebih menunjukkan kebijakan pemerintah yang top down, karena kebanyakan konsepnya lahir dari konsepsi pejabat atau pihak di luar desa, mengabaikan konteks lokal desa dan pemerintah cenderung menempatkan masyarakat sebagai objek kebijakan pemerintah semata (Sutoro Eko, 2004:216). Sehingga yang terjadi bukanlah tumbuhnya kemandirian dan daya saing desa, akan tetapi ketergantungan dan pragmatisme desa terhadap program pemerintah, desa juga hanya menjadi arena perebutan dukungan politik.

Selain beberapa problem di atas, ada persoalan lain yang lebih penting, yaitu paradigma pembangunan yang sangat sektoral. Masing-masing lembaga atau kementerian memiliki program ke desa sesuai urusannya, tanpa memperhatikan dimensi kewilayahan dan sinkronisasi dengan sektor lain. Tarigan berpendapat bahwa sebaiknya program pembangunan merupakan gabungan dari pendekatan sektor dan pendekatan regional (Tarigan, 2008:43). Lewis menyatakan bahwa perkembangan suatu wilayah akan mengalami stagnasi bila hanya satu sektor saja yang dikembangkan (Ernan Rustiadi, 2009:146). Hal tersebut berarti bahwa keberhasilan pembangunan merupakan upaya memadukan berbagai sektor dalam suatu wilayah tertentu. Keterpaduan tersebut membutuhkan pengelolaan yang terpadu dan kerjasama antar-stakeholder yang terlibat. Sehingga membangun desa adalah proses yang multi dimensional dan melibatkan segenap stakeholder yang saling bekerjasama. Pembangunan desa merupakan proses merespon tiga lingkungan desa (alam, budaya dan sosial ekonomi) dengan cara yang tepat (Daldjoeni \& Suyitno, 2004:37).

Berkaitan dengan hal tersebut, perlu dilakukan sebuah penelitian yang mendalam dengan menggabungkan kajian teoritis dan lapangan mengenai konsep-konsep pembangunan desa yang terpadu dan mengedepankan inovasi. Penelitian lapangan perlu dilakukan di desa yang memiliki keunggulan sesuai dengan kebutuhan di atas. Pertama ialah keunggulan pada proses keterpaduan program kegiatan, kedua adalah keunggulan pada inovasiinovasi pembangunan.

Sesuai dengan permasalahan di atas, maka tujuan yang hendak dicapai dalam penelitian ini ialah untuk:

1. Merumuskan model pembangunan desa yang berjalan secara terpadu dan mengedepankan inovasi sesuai dengan potensi lokal;

2. Mengetahui prasyarat yang diperlukan dalam pembangunan desa yang terpadu dan mengedepankan inovasi sesuai dengan potensi lokal;

3. Mendefinisikan peran masing-masing pihak dalam mewujudkan pembangunan desa yang terpadu dan mengedepankan inovasi sesuai dengan potensi lokal.

Hasil yang diharapkan dari penelitian ini adalah terbentuknya model pembangunan desa yang terpadu dan inovatif sebagai bahan pertimbangan pemerintah, pemerintah provinsi, pemerintah kabupaten dan pemerintah desa dalam rangka melaksanakan pembangunan desa untuk terwujudnya desa terpadu inovatif.

\section{METODE PENELITIAN}

\section{Pendekatan Penelitian}

Penelitian ini merupakan jenis penelitian deskriptif kualitatif yaitu pengumpulan, pengolahan dan interpretasi sejumlah data sebagai upaya untuk mengungkapkan kebenaran yang terdapat dalam masalah penelitian.

\section{Jenis, Teknik Pengumpulan dan Pengolahan Data}

Jenis data yang dikumpulkan adalah data sekunder dan data primer yang didapatkan melalui pengamatan lapangan, wawancara mendalam dan kuesioner. Analisis terhadap fakta dilangsungkan secara kualitatif dengan model Spradley.

\section{Subjek Penelitian}

Penelitian ini dilakukan di Desa Jatiroyo Kecamatan Jatipuro Kabupaten Karanganyar, Desa Samiran Kecamatan Selo Kabupaten Boyolali dan Desa Mlatiharjo Kecamatan Gajah Kabupaten Demak.

\section{Operasionalisasi Konsep}

a. Desa adalah kesatuan masyarakat hukum yang memiliki batas wilayah, yang berwenang untuk mengatur dan mengurus kepentingan masyarakat setempat, berdasarkan asal-usul dan adat istiadat setempat yang diakui dan dihormati

b. Pembangunan Desa Terpadu adalah pembangunan desa dilakukan usaha yang intensif dengan tujuan dan kecenderungan memberikan fokus perhatian kepada kelompok maupun daerah tertentu.

c. Pembangunan Desa Inovatif ialah kegiatankegiatan pemberdayaan melalui pembangunan dalam bentuk perbaikan mutu hidup dan perilaku 


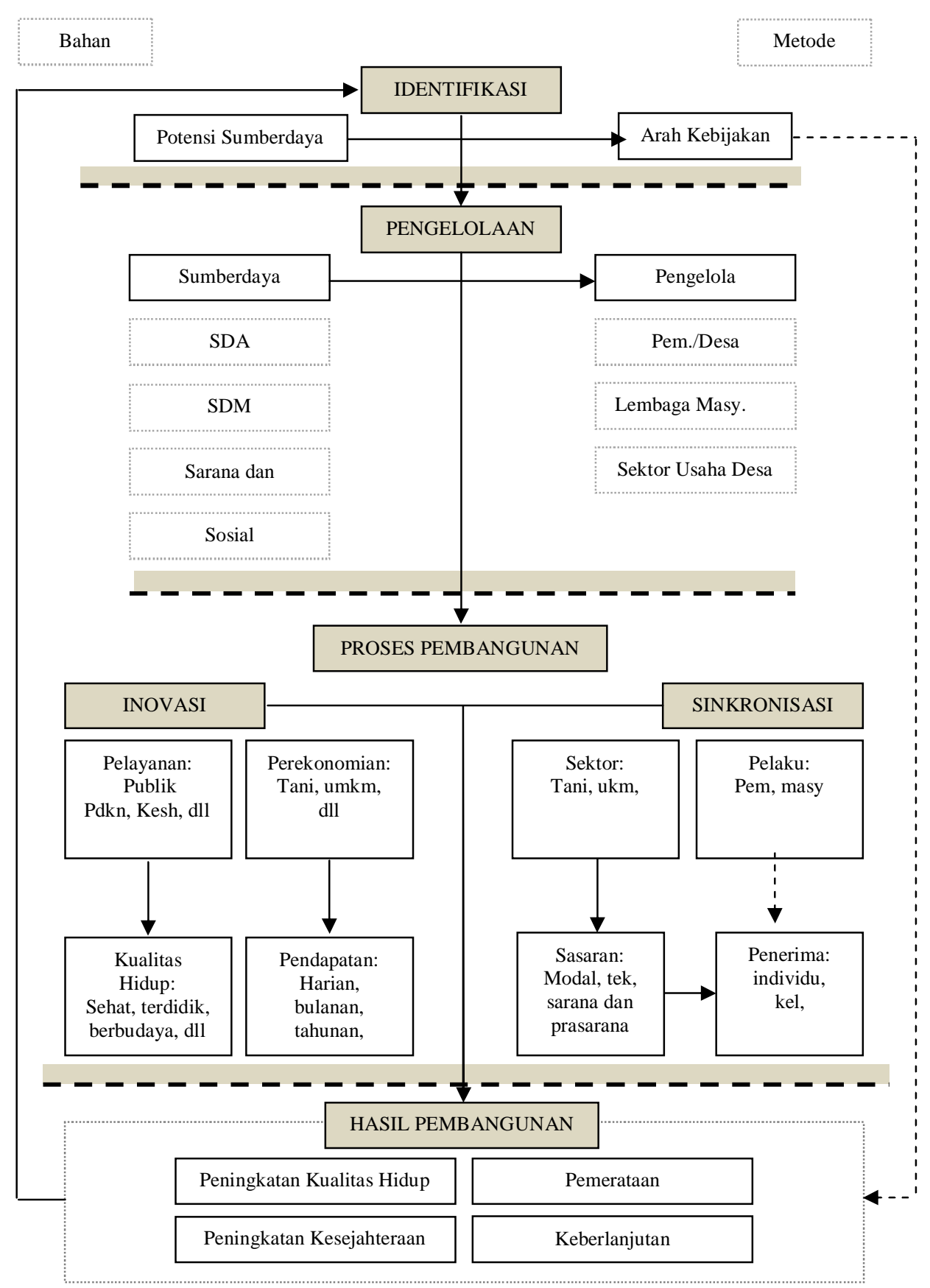

Gambar 1. Kerangka Komprehensif Model Pembangunan Terpadu Inovatif.

yang mencakup aspek peningkatan kemampuan masyarakat, peningkatan partisipasi masyarakat, meningkatkan kegiatan ekonomi masyarakat dan meningkatkan kemampuan SDM aparatur pemerintah desa berbasis Iptek.

\section{Waktu Pelaksanaan}

Penelitian ini dilakukan sekitar enam (6) bulan, terhitung mulai dari 1 Februari sampai dengan 30 Juli 2011.

\section{HASIL DAN PEMBAHASAN}

\section{Pembangunan Desa di Lokasi Penelitian}

\section{Desa Maltiharjo}

Desa Mlatiharjo yang berada di hamparan dataran rendah dengan sistem irigasi teknis yang bagus dan panas matahari yang cukup. Pertanian utama adalah tanaman pangan (padi), hortikultura dan buah. Dengan berbagai kodisi di atas, maka kepala desa menetapkan bahwa visi desa Mlatiharjo adalah: "Terwujudnya Jatidiri Desa Mlatiharjo". Jatidiri yang dimaksud di atas adalah bahwa desa mlatiharjo akan mengembangkan diri sebagai desa yang bertumpu pada pertanian dan peternakan.

Secara umum sumberdaya desa Mlatiharjo cukup memadai baik dari segi SDA, SDM, sarana dan prasarana maupun letak geografis yang cukup 
menguntungkan usaha tani. Kondisi tersebut mampu dioptimalkan oleh kepala desa dengan mengkoordinasikan berbagai sumberdaya dalam sebuah arah kebijakan. Ada beberapa sarjana yang dikoordinir oleh kepala desa yang memiliki budaya inovasi tinggi. Kelompok tersebut terdiri dari beberapa orang dekat kepala desa bahkan kerabatnya, sehingga mudah dikoordinir ke dalam sebuah misi. Semua pihak diberi peran sesuai dengan kemampuan dan latar belakang pendidikannya. Kemampuan masingmasing orang tersebut mampu disinkronkan menjadi pencapaian agenda pembangunan desa.

Kepala desa sebagai seorang sarjana pertanian memiliki peran yang besar dalam pengembangan inovasi di bidang pertanian, yaitu pemuliaan tanaman buah dan benih padi. Dengan memanfaatkan sumberdaya desa dan sumberdaya manusia di sekelilngnya, kepala desa bisa membangun konsep pembangunan yang visioner. Semua itu bisa dilakukan kepala desa karena secara pribadi yang bersangkutan memiliki sumberdaya memadai. Sebagai seorang yang berasal dari kalangan atas di desa (ayahnya juga mantan kepala desa), memiliki sumberdaya yang bisa dimanfaatkan untuk menjadi pemicu dan pendukung proses-proses tersebut di atas. Sumber keuangan desa berasal dari dari sewa tanah kas, produksi pupuk dan hasil pertanian secara berkelanjutan dengan hasil yang cukup besar. Pemanfaatan potensi alam dan sosial sudah mulai terlihat konsepnya. Konsep yang ditawarkan adalah menjadikan desa sebagai wahana wisata edukasi, terutama bidang pertanian.

Sinkronisasi program pembangunan desa secara umum berjalan dengan baik, akan tetapi dengan menggunakan metode yang kurang tertib. Dalam perencanaan dan pelaksanaan koordinasi dilakukan secara insidental, tidak terpola dan tanpa pembagian kewenangan dan tugas yang tegas antaraktor. Kepala desa mampu memanfaatkan potensi SDM secara maksimal, namun tidak terlembagakan secara baik. Pelaksanaan berbagai program bisa berjalan lancar dengan dukungan sumberdaya yang memadai, namun dokumentasi dan tertib administrasinya kurang. Kepala desa juga mampu menjalin kerjasama dengan berbagai pihak untuk meningkatkan kapasitas desa.

Kepala desa memiliki kapasitas yang memadai dalam visi dan arah kebijakan pembangunan. Akan tetapi dalam poses pengelolaan, manajemen yang digunakan masih belum terorganisir dengan baik. Perhatian utama saat ini ialah fokus pada kinerja, setelah stabil baru kelembagaan dibangun dengan konsep yang mapan. Arahan dan tahapan pembangunan juga belum tersusun dengan baik. Kelemahan utama ialah pada manajemen yang masih belum tertata dengan baku.

Kepala desa Mlatiharjo selalu menjalin kerjasama dengan berbagai pihak terkait, inovasiinovasi bidang pengembangan pertanian dilakukan dengan UKSW Salatiga. Kerjasama dalam mekanisasi alat-alat pertanian dilakukan dengan Polines Semarang. Pemuliaan benih padi dan buah dilakukan dengan para pakar dari balai inseminasi dan pemuliaan tanaman Kementerian Pertanian.

Desa Mlatiharjo juga mulai merintis penggunaan teknologi informasi untuk sektor pelayaan publik, akan dibuat sistem terintegrasi sehingga begitu terjadi proses pelayanan dan terdapat perubahan data, maka database akan berubah secara kontinyu. Tujuan penggunaan teknologi informasi adalah untuk menuju pelayanan pemerintah berbasis teknologi informasi atau e-government.

Pada sektor pendidikan, ada kerjasama antara kepala desa dengan pihak yang memiliki kompetensi untuk membangun sekolah menengah kejuruan. Sekolah tersebut mengkhususkan dirinya pada jurusan pertanian. Hal ini sesuai dengan potensi lokal. Tujuan kedepan adalah menciptakan SDM desa yang berkualitas untuk kemajuan usaha tani desa.

Inovasi sesuai visi desa dilakukan dalam bidang peternakan dan pertanian. Fokusnya adalah pada menciptakan bibit unggul yang spesifik lokal dan memiliki karakteristik yang berbeda dengan daerah lainnya. Inovasi juga dilakukan dalam mekanisasi pertanian. Kepala desa sebagai seorang sarjana pertanian dan pengurus HKTI di tingkat kabupaten, memiliki jaringan yang luas. Kepala desa bisa menciptakan jenis padi baru yang spesifik, yaitu varietas Melati dan Sulthan. Kepala desa juga mengembangkan jenis padi organik dengan memanfaatkan tanahnya dan tanah kas desa untuk proses uji coba berbagai varietas padi.

Melalui jaringannya kepala desa bisa mendapatkan beberapa jenis buah unggulan. Pohon nangka sudah ditanam hampir di setiap pekarangan penduduk. Selain itu dikembangkan buah lengkeng. Keberhasilannya adalah bisa menjadikan lengkeng berbuah dengan kualitas yang lebih bagus dengan daerah lainnya. Walaupun lokasi desa berada di ketinggian 6 meter di atas permukaan laut (dpl), namun lengkeng bisa tumbuh dan berbuah. Selama ini lengkeng hanya ditanam di dataran tinggi, di atas 350 meter dpl.

Pada sektor peternakan, dilakukan pengembangan jenis kambing karena potensi pasar yang besar dan siklus yang relatif singkat. Selain sebagai pedaging, kambing juga diambil susunya. Bibit kambing yang sedang diupayakan adalah yang memiliki badan kecil dan mampu memproduksi banyak susu. Lahan-lahan yang kosong juga bisa ditanam pohon kayu-kayuan. Konsep ini merupakan upaya untuk memperkuat ketahanan pangan masyarakat desa. Sehingga masyarakat memiliki sumber penghidupan yang bisa mencukupi kebutuhan harian seperti ayam atau itik, memiliki tabungan bulanan seperti kambing atau domba dan tabungan tahunan berupa sapi atau pohon kayu.

Sebagai dukungan terhadap konsep pertanian dan peternakan di atas, dilakukan pembuatan pupuk dan pestisida organik serta pakan ternak yang berbahan dasar barang-barang yang banyak terdapat di desa, seperti jerami. Pupuk dan pestisida untuk 
memulai meninggalkan ketergantunagn terhadap pupuk dan pestisida kimia yang membahayakan kelangsungan daya dukung tanah.

Ada beberapa output pembangunan yang merupakan produk inovasi dari masyarakat. Inovasi tersebut berpotensi sebagai produk unggulan desa. Di bidang lain, inovasi bisa meningkatkan pelayanan kepada masyarakat. Dalam bidang pertanian, telah dihasilkan bibit padi jenis baru yaitu Melati dan Sulthan. Pertanian organik sedang dikembangkan dan kedepan akan dibentuk kelembagaan klaster yang meliputi beberapa desa. Budidaya buah-buahan yang potensial seperti nangka dengan keunggulan khusus, lengkeng, pisang dan buah lainnya. Inovasi pupuk juga dilakukan dengan memanfaatkan sumberdaya yang ada di desa, terutama kotoran ternak. Dalam peternakan sedang diupayakan penciptaan jenis spesies kambing yang baru sesuai selera pasar..

Selain keunggulan di atas, ada beberapa kelemahan yang terjadi.Inovasi sangat tergantung pada figur kepala desa dan beberapa warga, tidak terlembagakan dalam pemerintahan desa. Inovasiinovasi yang dilakukan cenderung sebagai milik kepala desa dan orang-orang terdekatnya, bukan merupakan aset desa. Untuk ke depan, keberlanjutan pembanguan dan inovasi kurang bermakna bagi desa ketika tidak dimulai proses transformasi kepada unsur desa dan masyarakat lainnya. Selain itu, kepala desa juga kurang melibatkan aparat secara maksimal, sehingga tertib administrasi dan prosedur pelayanan publik kurang menjadi perhatian. Ke depan perlu diperhatikan sebagian peningkatan pelayanan publik melibatkan aparat desa, sehingga menjadi pembaruan yang berkelanjutan.

\section{Desa Samiran}

Sebagai daerah yang terletak di pegunungan dan merupakan jalur celah antara gunung Merapi dan Merbabu serta jalur kawasan wisata Solo-SeloBorobudur, maka potensi yang dapat ditingkatkan adalah sektor pertanian, peternakan, pariwisata, umkm pendukung pariwisata. Berdasarkan kondisi tersebut di atas, kepala desa bersama segenap stakeholder desa menetapkan visi sebagai berikut "Mendorong terwujudnya masyarakat dan Pemerintah desa Samiran yang aman, maju, sehat dan sejahtera”.

Untuk memaksimalkan pembangunan desa, kepala desa sangat aktif mencari bantuan dan program-program dari pemerintah sebagai penopang utama keuangan desa. Kepala desa mengkoordinir dengan baik pelaksanaan program-proram tersebut dengan sasaran masing-masing, tetapi saling melengkapi. Kendala kepala desa adalah belum tersedianya daya dukung SDM aparatur pemerintah desa yang mampu mendukung kinerja kepala desa. Sebagian perangkat sudah berusia lanjut dan tidak mudah diajak bekerjasama sesuai visi kepala desa terutama dalam hal menyesuaikan dengan kinerja kepala desa. Untuk memulai peningakatan kinerja, kepala desa mendelegasikan urusan melegalisir KTP kepada kaur pemerintahan. Strategi kepala desa untuk mengahadapi persoalan perangkat desa adalah dengan memanfaatkan kelembagaan masyarakat yang ada yang dianggap mampu menjalankan tugas pembangunan.

Kendala yang dihadapi desa adalah minimnya pendapatan desa. Dana yang berasal dari hasil sewa tanah kas dan ADD hanya cukup untuk biaya operasional desa, sedangkan untuk pembangunan perlu dukungan dari luar. Untuk menyikapi kondisi tersebut, kepala desa aktif mencari sumber pendanaan dan bantuan proyek dari berbagai pihak.

Keunggulan Samiran adalah banyak program yang masuk sehingga membantu pembangunan desa. Banyaknya program proyek tersebut didorong karena lemahnya sumberdaya keuangan desa. Pendapatan yang kurang memadai terbantu dengan berbagai proyek, akan tetapi hal ini menjadi persoalan di kemudian hari ketika kepala desa tidak mampu mendatangkan berbagai proyek dan dana tambahan.

Banyaknya program-program tersebut tidak saling berbenturan satu dengan lainnya. Semua program bisa dikoordinasikan oleh kepala desa melalui koordinasi rutin antarpelaku program dan penerima program. Swadaya masyarakat untuk program-program yang ada juga cukup baik. Terjadi kerjasama dalam pembangunan, misalnya program PNPM Mandiri memiliki kegiatan pembangunan sarana prasarana, kemudian pemerintah desa menyediakan lahan kas desa untuk dibangun gedung BLM dari dana PNPM Mandiri. Pelaksanaan program PNPM Mandiri dan JRF Rekompak dikoordinir oleh kepala desa, sehingga sasaran program dapat saling melengkapi.

Perencanaan pembangunan sangat partisipatif, musrenbangdes diikuti aparat desa, lembaga-lembaga desa, RT/RW dan perwakilan dusun, LSM, dinas dan satker kecamatan. Dalam monitoring program, perumusan review RPJM Des dan RKPDes diikuti perwakilan lembaga masyarakat (masing-masing 2 orang) sebagai perumus RPJMDes. Kepala desa telah memulai proses pemberdayaan masyarakat dalam segala aspek pemerintahan desa. Selain agar semua unsur desa mengetahui dan terlibat dalam proses pembangunan, juga adanya proses keberlanjutan pembangunan. Agenda pembangunan, perumusan program, pelaksanaan pengawasan dan evaluasi melibatkan segenap unsur desa. Kepala desa juga aktif turun ke pertemuan warga untuk menyerap aspirasi. Sehingga secara politis, kepala desa telah melakukan demokratisasi yang substansial. Kepala desa juga mampu mengajak segenap pihak pelaksana program dan kelembagaan masyarakat untuk menyatukan pemahaman.

Dalam bidang pertanian, kedepan dengan konsep STA (Sub Terminal Agribisnis), diharapkan memiliki pasar sendiri. Selama ini sayur produk Samiran dan Kecamatan Selo pada umumnya dijual di pasar kecamatan Cepogo. Biogas juga mulai dikembangkan untuk mandiri energi. Dengan konsep 
Agro Silvo Pastural yaitu pertanian, peternakan dan kehutanan menjadi keunggulan desa kedepan. Gapoktan sebagai induk kelompok petani di desa akan dikembangkan menjadi organisasi yang kuat sebagai wadah bagi pengembangan usaha tani, kendala dana menjadi masalah klasik. Kendala lain pertanian adalah musim yang tidak menentu dan masih kurangnya pemeliharaan sapi ternak, untuk mengatasi kendala tersebut warga mengharap agar dari pemerintah memberikan hibah ternak sapi.

Inovasi dalam bidang peternakan yang memiliki daya ungkit adalah mengubah produk susu menjadi keju, yang dilaksanakan dengan dukungan kerjasama dengan kosultan dari Belanda. Selama ujicoba, sebagaimana disampaikan Kepala Desa Samiran uji coba berhasil dan akan dikembangkan menjadi industri keju.

Di sektor UMKM, ada beberapa home indsutry, seperti gula klethak, jadah, dll. Selain itu berbagai macam hasil pertanian, sayur, tembakau, budidaya jamur kuping, kerajinan bambu wulung, dan lainya. Sektor tersebut juga menjadi pelengkap wisata Samiran. Untuk itu BLM dipergunakan semaksimal mungkin untuk membina SDM dalam meningkatkan kualitas produk.

Bentuk inovatif lainnya dalam bidang ekonomi adalah pemanfaatan aset desa untuk meningkatkan pedapatan. Dengan memanfaatkan sumberdaya berbagai program, terutama PNPM Mandiri dan aset desa, telah dibangun gedung pelatihan yang diberi nama Balai Latihan Masyarkat (BLM) dan kedepan akan dibangun gedung serbaguna dilengkapi dengan penginapan. Konsep ini menangkap peluang posisi Samiran di pegunungan yang sering digunakan sebagar tempat acara seminar, pelatihan, kursus dan lainnya oleh berbagai pihak.

\section{Desa Jatiroyo}

Secara geografis letak desa yang kurang srategis berada di pedalaman, sehingga panduduk hanya bisa mengandalkan pertanian dan sumberdaya alam lain seperti penambangan batu dan pasir. Kepemilikan lahan yang relatif tidak luas sehingga pendapatan penduduk juga tidak terlalu tinggi, untuk itu sebagian besar warga merantau ke luar daerah untuk mencari penghasilan yang labih baik. Pertanian bisa dibedakan menjadi pertanian jangka pendek, dengan menanam hortikultura, seperti padi, jagung, ubi kayu, sayur-sayuran. Sedangkan pertanian jangka panjang meliputi tanaman kayu seperti sengon, jati, dan buah-buahan seperti durian, rambutan, dan mangga. Kelebihan perencanaan pembangunan desa adalah pelibatan segenap unsur desa. Setiap program pembangunan juga diintegrasikan ke dalam APBDes meskipun berasal dari sumber lain. Pemerintah desa juga mampu merangkul berbagai unsur dan dimanajemen dengan baik oleh sekretaris desa secara kompeten.

Kepala desa berperan sebagai fasilitator dan masyarakat berperan lebih aktif dalam pembangunan.
Administrasi pembangunan cukup baik, semua program dari luar seperti PNPM Mandiri, PDT dimasukkan dalam dokumen APBDes. Kinerja aparat cukup tertib, ada sistem jaga untuk setiap aparat, sehingga pelayanan kantor desa berjalan lancar. Dianggarkan dalam APBDes untuk peningkatan kinerja aparat, namun sering tidak terlaksana karena anggaran tidak mencukupi

Untuk urusan perekonomian, pemerintah desa bekerjasama dengan masyarakat. BUMDes dan pasar desa dikelola oleh masyarakat dan pemerintah desa hanya memfasilitasi. Tanah kas desa pengelolaannya dilakukan oleh keluarga miskin dengan proporsi bagi hasil $50 \%$ penggarap/pemelihara, $50 \%$. Pada sektor UMKM, ada beberapa potensi industri lokal/home industry di desa Jatiroyo yang nantinya bisa dikembangkan dengan bantuan BUMDes, yaitu home industry tahu tempe, rambak, anyam-anyaman bambu, merangkai bunga kering, gypsum, mebeler/pertukangan, bengkel cat duko, penjahit, perbengkelan mesin dan pengelolaan hasil ternak/perikanan. Potensi-potensi tersebut dapat dikembangkan dengan dukungan modal dan pendampingan bisnis. Pelatihan-pelatihan sudah mulai dilakukan untuk meningkatkan kapasitas dan ketrampilan masyarakat. Program PNPM Mandiri juga fokus pada upaya tersebut.

Terdapat kerjasama yang erat antarpelaku program dan dukungan masyarakat. Koordinasi pembangunan menghasilkan sinergisitas pembangunan desa. Setiap 35 hari sekali ada forum selapanan baik di kelompok gapoktan maupun paguyuban RT/RW sebagai sarana sosialisasi dan koordinasi antaraktor pelaku program pembangunan, sekaligus meningkatkan partisipasi masyarakat. Dalam forum tersebut, pengelolaan program PNPM Mandiri maupun Pembangunan Desa Terpadu (PDT) juga hadir memberikan sosialisasi dan informasi kepada masyarakat.

Ada 2 program dari luar yang utama di desa Jatiroyo, yaitu PNPM Mandiri dan PDT. Pelaku program seperti PNPM Mandiri dan PDT aktif melakukan sosialisasi dan koordinasi kepada warga melalui dusun maupun forum RT/RW. Ada koordinasi antara PNPM Mandiri dan PDT sehingga tidak tumpang tindih dan saling melengkapi. Pembangunan pasar desa dibiayai oleh program PDT dan swadaya masyarakat, termasuk pembelian lahan. PNPM Mandiri memberikan fasilitasi pelatihan kepada masyarakat dan perbaikan sarana jalan desa.

Dalam perencanaan dan pelaksanaan selalu ada koordinasi antarpelaku agar tidak terjadi kesamaan sasaran. Melalui musrenbangdes dibahas berbagai kegiatan di desa. Secara administratif setiap kegiatan dimasukkan dalam APBDes secara tertib, biasanya program PDT tengah tahun, PNPM awal tahun. Sebagian warga bisa berperan aktif walaupun masih terbatas pada pihak-pihak tertentu.

PNPM Mandiri yang mulai dilaksanakan tahun 2010 sudah menghasilkan pembangunan selaras 
dengan pembangunan lainnya. Program PDT menghasilkan pasar desa, simpan pinjam dan lumbung pangan. Pembangunan pasar desa dengan juga dengan bantuan swadaya masyarakat. Rencana ke depan kios pasar desa akan disewakan. Simpan pinjam kepada seluruh masyarakat dengan menggunakan agunan berupa sertifikat tanah atau BPKB, simpan pinjam juga diberikan di kelompok PKK.

Gapoktan yang terdiri dari 11 kelompok tani, setiap 35 hari sekali ada pertemuan dan berkoordinasi dengan pihak lain, gapoktan juga memanfaatkan pasar desa serta BUMDes untuk kemajuan usaha tani. Penyaluran pupuk subsidi dilakukan oleh gapoktan, tetapi masih terkendala permodalan. Para petani mulai membuat pupuk kompos, obat tanaman buah.

Hasil pertanian berupa padi, jagung, ketela pohon, dan sudah 5 tahun ini produksi jagung meningkat. Namun penjualan masih cenderung dilakukan perseorangan, sehingga akan dirintis penjualan bersama. Harapan kedepan bisa dikoordinir oleh gapoktan dan memanfaatkan pasar desa. Peningkatan produksi jagung masih membutuhkan bantuan permodalan, pupuk dan benih.

Kepala desa selalu melakukan konsolidasi setiap senin untuk mengevaluasi kinerja mingguan dan membahas kegiatan berikutnya. Pemerintah desa mengupayakan peningkatan kapasitas melalui pelatihan dan pembinaan. Dalam APBDes dianggarkan dana untuk pelatihan-pelatihan aparat. Ada aparat yang piket di kantor setiap hari dan para kadus setiap 2 minggu sekali masuk di kantor desa. Ada koordinasi antarkadus, dibentuk 2 kelompok kadus, masing-masing 5 orang dan diberi wewenang untuk menyelesaikan masalah, jika tidak bisa maka diselesaikan di desa.

Tanah kas desa yang kurang produktif juga dimanfaatkan untuk penanaman kayu yang produktif seperti sengon. Selain itu, pembangunan pasar desa dan BUMDes berpotensi menjadi penguat perekonomian desa dan menjadi daya ungkit perekonomian desa kedepan.

Secara umum, pembangunan bidang pertanian masih menghadapi kendala saat ini yaitu kurangnya permodalan untuk mengembangkan BUMDes. Petani juga merasakan kurangnya sarana sentra penjualan hasil pertanian, khusunya gudang untuk menampung hasil tanaman. Selain itu daya saing produk pertanian masih lemah, kurangnya inovasi dan penguatan pasar. Potensi tanaman obat (empon-empon) belum dikembangkan dengan baik sebagaimana desa-desa di sekitarnya. Bidang peternakan kurang berkembang dan masih dikelola secara tradisional oleh petani.

Pembangunan UMKM dilakukan dengan penyaluran bantuan kepada masyarakat. Ada beberapa lembaga keuangan mikro sebagai hasill pelaksanaan program PNPM Mandiri dan PDT yaitu simpan pinjam perempuan (SPP), Lembaga Simpan Pinjam Berbasis Masyarakat (LSPBM), PKK dan lainnya. Lembaga-lembaga keuangan mikro tersebut sangat membantu permodalan masyarakat dalam manajemen usahanya.

Kelemahan utama desa Jatiroyo adalah perekonomian mengandalkan pada proses eksploitasi sumberdaya alam, bukan pemanfaatan yang berorientasi berkelanjutan. Ketidakadaan daya dukung sumberdaya alam habis, maka produktiftas akan semakin menurun. Untuk itu perlu dipikirkan sebuah metode pemanfaatan sumberdaya alam yang bisa diperbaharui.

\section{Model Pembangunan Desa Terpadu Inovatif}

Perubahan paradigma pembangunan dari mengutamakan indikator kuantitatif kepada keseimbangan dengan indikator kualitatif. Kegagalan pembangunan berbasis pertumbuhan, menciptakan paradigma baru yang meyakini bahwa pembangunan harus diarahkan kepada terjadinya pemerataan (equity), pertumbuhan (eficiency), dan keberlanjutan (sustainability) yang berimbang dalam pembangunan ekonomi.

Mengubah prinsip pertumbuhan semata menjadi prinsip pemerataan (equity), pertumbuhan (eficiency) dan keberlanjutan (sustainability) menjadi sangat penting bagi pembangunan desa masa kini. Todaro telah menyatakan bahwa pembangunan harus dipandang sebagai suatu proses multidimensional yang mencakup berbagai perubahan mendasar atau struktur sosial, sikap-sikap masyarakat, dan institusiinstitusi nasional, disamping tetap mengejar akselerasi pertumbuhan ekonomi, maka perlu melibatkan segenap stakeholder yang saling bekerjasama. Pembangunan desa merupakan proses merespon tiga lingkungan desa (alam, budaya dan sosial ekonomi) dengan cara yang tepat, maka dalam pembangunan harus diperhatikan unsur lingkungan tersebut.

Desa Samiran telah menunjukkan bahwa dengan keterbatasan keuangan, namun pelaksanaan upaya koordinasi, pemerataan dan partisipasi, arah pembangunan dapat menghasilkan sebuah keunggulan tersendiri. Desa Jatiroyo dengan ketergantungannya terhadap pihak luar, berusaha memanfaatkan yang didapatnya untuk kebutuhan pokok mereka. Sedangkan desa Mlatiharjo, meskipun dengan manajemen yang sangat tidak memadai, melakukan penggalian potensi yang tersembunyi dari kearifan lokal manusia-manusia desa yang berkualitas.

Selain pertumbuhan, pemerataan dan keberlanjutan merupakan tujuan utama pembangunan. Pemerataan baik secara wilayah, sektoral maupun penerima atau pemanfaat pembangunan merupakan ukuran penting keber-hasilan pembangunan. Keberlanjutan pembangunan tidak saja memenuhi kebutuhan sesaat, tetapi menjaga bagaimana terjadi kesinambungan dana agar manfaatnya bisa dirasakan lintas generasi. Dari konsep-konsep tersebut di atas, berikut gambaran yang lebih komprehensif mengenai siklus pembangunan terpadu inovatif yang dapat dirumuskan dalam penelitian ini. 
Tabel 1. Kerangka Umum Pembangunan Desa Inovatif

\begin{tabular}{|c|c|c|c|}
\hline No & Indikator & Situasi yang Diharapkan & Kegiatan yang Perlu dilakukan \\
\hline 1. & $\begin{array}{l}\text { Identifikasi } \\
\text { Potensi }\end{array}$ & Tersedianya peta potensi desa & Inventarisasi potensi desa \\
\hline a. & SDM & $\begin{array}{l}\text { Aparat: tersedianya SDM aparatur yang } \\
\text { mampu menjalankan tugas dengan baik, } \\
\text { kapasitas mampu mendukung visi-misi kades } \\
\text { Masyarakat: kapasitas masyarakat mampu } \\
\text { mendukung program pembangunan, } \\
\text { penguasaan iptek baik, modal sosial kuat }\end{array}$ & $\begin{array}{l}\text { Aparat: melakukan konsolidasi rutin berkala, } \\
\text { peningkatan kemampuan melalui pelatihan, } \\
\text { pendidikan, dll yang bisa dikoordinir pemda } \\
\text { Masyarakat: memanfaatkan berbagai media } \\
\text { untuk pembelajaran masyarakat }\end{array}$ \\
\hline b. & SDA & $\begin{array}{l}\text { Potensi sumberdaya alam terjaga dengan } \\
\text { baik, dikelola dengan prinsip keberlanjutan, } \\
\text { menjaga kelestarian dan daya dukung } \\
\text { kedepan }\end{array}$ & $\begin{array}{l}\text { Melakukan inovasi untuk menghindari } \\
\text { eksploitasi berlebihan dan ketergantungan } \\
\text { kepada sumberdaya alam }\end{array}$ \\
\hline c. & $\begin{array}{l}\text { Sarana dan } \\
\text { prasarana }\end{array}$ & $\begin{array}{l}\text { Tersedianya sarana dan prasarana fisik yang } \\
\text { mendukung pembangunan }\end{array}$ & $\begin{array}{l}\text { Memaksimalkan aset desa untuk pelaksanaan } \\
\text { pembangunan dan menjaga yang ada }\end{array}$ \\
\hline d. & $\begin{array}{l}\text { Sumberdaya } \\
\text { Sosial }\end{array}$ & $\begin{array}{l}\text { Partisipasi masyarakat serta tersedianya } \\
\text { lembaga masyarakat sebagai pelaku } \\
\text { pembangunan }\end{array}$ & $\begin{array}{l}\text { Mengedepankan lembaga masyarakat sebagai } \\
\text { pelaksana utama pembangunan }\end{array}$ \\
\hline 2. & Perencanan & $\begin{array}{l}\text { Perencanaan pembangunan yang } \\
\text { mengakomodasi semua pihak dan seluruh } \\
\text { rencana program pembangunan yang akan } \\
\text { dilakukan baik secara strategis ( } 5 \text { tahunan) } \\
\text { maupun secara teknis (tahunan) }\end{array}$ & $\begin{array}{l}\text { Menetapkan arah pengembangan strategis, } \\
\text { melibatkan masyarakat luas, mengakomodasi } \\
\text { kepentingan berbagai pihak dan sektor serta } \\
\text { memadukan kerangka pembangunannya }\end{array}$ \\
\hline 3. & $\begin{array}{l}\text { Pengelolaan } \\
\text { Sumberdaya }\end{array}$ & & \\
\hline a & Sumberdaya & $\begin{array}{l}\text { Terbangunnya pola pemanfaatan } \\
\text { sumberdaya yang optimal dan manajemen } \\
\text { yang efektif dan efisien }\end{array}$ & $\begin{array}{l}\text { Peningkatan kemampuan SDM dalam bidang } \\
\text { manajemen sumberdaya melalui pelatihan dan } \\
\text { kerjasama }\end{array}$ \\
\hline b & Pengelola & $\begin{array}{l}\text { Sumberdaya dikelola oleh pihak yang tepat } \\
\text { dan kompeten, memiliki landasan kekuatan } \\
\text { hukum dan diakui legitimasinya }\end{array}$ & $\begin{array}{l}\text { Adanya kesepakatan warga desa mengenai } \\
\text { siapa yang diberi wewenang mengelola } \\
\text { sumberdaya-sumberdaya yang ada secara tepat }\end{array}$ \\
\hline 4. & Sinkronisasi & & \\
\hline a & Pelaku & $\begin{array}{l}\text { Terbangunnya pola komunikasi, koordinasi } \\
\text { dan kerjasama antarpelaku pembangunan di } \\
\text { desa }\end{array}$ & $\begin{array}{l}\text { Peran aktif pemerintah desa dan lembaga } \\
\text { masyarakat dalam mengarahkan para pelaku } \\
\text { pembangunan }\end{array}$ \\
\hline$b$ & Sektor & Saling terkaitnya pembangunan antarsektor & $\begin{array}{l}\text { Koordinasi antarpelaku, pemerintah desa dan } \\
\text { masyarakat }\end{array}$ \\
\hline $\mathrm{c}$ & Sasaran & $\begin{array}{l}\text { Sasaran pembangunan yang tepat dan tidak } \\
\text { tumpang tindih }\end{array}$ & $\begin{array}{l}\text { Koordinasi antarpelaku, pemerintah desa dan } \\
\text { masyarakat }\end{array}$ \\
\hline $\mathrm{d}$ & Penerima & $\begin{array}{l}\text { Penerima program tidak tumpang tindih dan } \\
\text { menerima manfaat program dengan baik }\end{array}$ & $\begin{array}{l}\text { Peran aktif pemerintah desa dan lembaga } \\
\text { masyarakat dalam mengarahkan para pelaku } \\
\text { pembangunan }\end{array}$ \\
\hline 5. & Inovasi & & \\
\hline a & Perekonomian & $\begin{array}{l}\text { Peningkatan produktifitas masyarakat } \\
\text { berbasis iptek }\end{array}$ & $\begin{array}{l}\text { Mendorong dan memfasilitasi inovasi teknologi } \\
\text { tepat guna }\end{array}$ \\
\hline $\mathrm{b}$ & Pendapatan & $\begin{array}{l}\text { Peningakatan pendapatan masyarakat sebagai } \\
\text { hasil keunggulan produk yang kompetitif }\end{array}$ & $\begin{array}{l}\text { Implementasi teknologi tepat guna dalam } \\
\text { semua aspek usaha masyarakat desa }\end{array}$ \\
\hline $\mathrm{c}$ & Pelayanan Publik & Peningkatan pelayanan publik berbasis iptek & $\begin{array}{l}\text { Mendorong dan memfasilitasi inovasi dan } \\
\text { teknologi tepat guna }\end{array}$ \\
\hline $\mathrm{d}$ & Kualitas Hidup & $\begin{array}{l}\text { Peningkatan kualitas hidup sebagai hasil } \\
\text { pelayanan yang baik }\end{array}$ & $\begin{array}{l}\text { Implementasi teknologi tepat guna dalam } \\
\text { semua aspek pelayanan publik }\end{array}$ \\
\hline 6. & $\begin{array}{l}\text { Hasil } \\
\text { pembangunan }\end{array}$ & & \\
\hline a & $\begin{array}{l}\text { Peningkatan } \\
\text { Kesejahteraan }\end{array}$ & $\begin{array}{l}\text { Peningkatan pendapatan masyarakat sebagai } \\
\text { hasil dari peningkatan kualitas maupun } \\
\text { kuantitas produksi serta penguatan pasar. } \\
\text { Penggunaan sumberdaya sekecil mungkin } \\
\text { untuk menghasilkan sebanyak mungkin } \\
\text { keuntungan }\end{array}$ & $\begin{array}{l}\text { Kerjasama dengan berbagai pihak penyedia } \\
\text { inovasi, pemanfaatan inovasi secara tepat, } \\
\text { pembentukan kelembagaan yang kuat. } \\
\text { Pemanfaatan inovasi yang tepat, kerjasama } \\
\text { antarpelaku pembangunan, pengawasan terpadu } \\
\text { oleh segenap unsur desa terhadap pelaksanaan } \\
\text { pembangunan }\end{array}$ \\
\hline $\mathrm{b}$ & $\begin{array}{l}\text { Peningkatan } \\
\text { kulitas hidup }\end{array}$ & $\begin{array}{l}\text { Peningkatan kualitas hidup masyarakat } \\
\text { sebagai hasil pembangunan yang terpadu dan } \\
\text { memanfaatkan inovasi-inovasi teknologi } \\
\text { tepat guna }\end{array}$ & $\begin{array}{l}\text { Kerjasama dengan berbagai pihak pelaku } \\
\text { pembangunan, pemanfaatan inovasi secara } \\
\text { tepat, pembentukan kelembagaan yang kuat }\end{array}$ \\
\hline $\mathrm{c}$ & Pemerataan & Penerima manfaat pembangunan merata & $\begin{array}{l}\text { Perencanaan yang komprehensif dalam bentuk } \\
\text { rencana strategis pembangunan desa, dengan } \\
\text { melibatkan segenap unsur desa }\end{array}$ \\
\hline d & Keberlanjutan & $\begin{array}{l}\text { Pemanfaatan sumberdaya memperhatikan } \\
\text { generasi mendatang, orientasi dan sasaran }\end{array}$ & $\begin{array}{l}\text { Upaya perencanaan yang mampu } \\
\text { mengakomodir berbagai kebutuhan masyarakat }\end{array}$ \\
\hline
\end{tabular}




\begin{tabular}{|c|c|c|}
\hline No $\quad$ Indikator & Situasi yang Diharapkan & Kegiatan yang Perlu dilakukan \\
\hline & $\begin{array}{l}\text { pembangunan tidak parsial (proyek) tetapi } \\
\text { kontinyu }\end{array}$ & $\begin{array}{l}\text { dan keberadaan berbagai macam program } \\
\text { pembangunan dalam satu arah kebijakan serta } \\
\text { mengedepankan inovasi untuk menghindari } \\
\text { ekpsloitasi berlebih dan ketergantungan } \\
\text { terhadap SDA }\end{array}$ \\
\hline
\end{tabular}

\section{SIMPULAN}

Model pembangunan terpadu inovatif merupakan siklus pembangunan yang dimulai dari proses identifikasi potensi sumberdaya dan kemudian menentukan arah pembangunan yang melibatkan segenap unsur desa. Setelah ditentukan arah pembangunan, pengelolaan sumberdaya desa perlu ditetapkan secara tepat dan benar. Kemudian inti dari pembangunan terpadu inovatif adalah proses yang mengutamakan sinkronisasi antarsektor dan antarpelaku serta mengedepankan inovasi dalam berbagai bidang sebagai tekniknya. Dengan demikian, hasil pembangunan akan menciptakan pertumbuhan, pemerataan dan keberlanjutan. Hasil-hasil tersebut akan menjadi bahan masukan bagi pembangunan tahap berikutnya.

Dengan memperhatikan praktik di lokasi penelitian dan penjelasan teoritis di atas, maka prasyarat pembangunan desa terpadu inovatif adalah:

a. Teridentifikasinya potensi sumberdaya dan arah pembangunan;

b. Terlaksananya pengelolaan sumberdaya yang tepat guna;

c. Terciptanya sinkronisasi dalam pelaksanaan pembangunan;

d. Menumbuhkan inovasi sebagai teknik pembangunan; serta

e. Hasil pembangunan mencakup unsur pertumbuhan, pemerataan dan keberlanjutan.

Berasarkan situasi di lapangan penelitian dan penjelasan teoritis sebelumnya, maka peranan yang perlu dilakukan oleh masing-masing pihak terkait dalam pembangunan desa adalah:

a. Pemerintah, pemerintah provinsi, pemerintah kabupaten harus konsisten dan terarah dalam merumuskan arah kebijakan, menentukan bentuk program, implementasi program secara terkoordinir dan proses monitoring dan evaluasi yang terpadu;

b. Pemerintah desa melakukan identifikasi potensi dan menentukan arah kebijakan, membangun koordinasi dan sinkronisasi serta memberikan fasilitasi dan mengedepankan pemberdayaan masyarakat;

c. Masyarakat desa dan lembaga kemasyarakatan desa berpartisipasi dan melakukan pengawasan;

d. Akademisi memberikan masukan iptek dan pendampingan; dan

e. Pelaku usaha melakukan investasi dan kerjasama.
Dengan demikian, keberhasilan pembangunan desa tidaklah kinerja unsur-unsur internal desa semata, melainkan kerja bersama berbagai pihak.

Berdasarkan simpulan penelitian di atas, maka penelitian ini menghasilkan saran kepada berbagai pihak sebagai berikut:

a. Agar model pembangunan desa terpadu inovatif bisa menjadi konsep yang benar-benar mejawab persoalan perlu uji coba implementasinya di beberapa desa melalui program terarah dan sistematis. Kemudian dilakukan evaluasi untuk menilai efektifitasnya serta memperbaiki konsepnya. Proses ini perlu melibatkan berbagai unsur lembaga pemerintah dan akademisi serta pelaku usaha;

b. Penciptaan prasyarat pembangunan terpadu inovatif perlu dilakukan oleh pemerintah desa dan segenap unsur desa mulai melakukan berbagai pembenahan dalam menetapkan arah kebijakan pembangunan desa. Proses tersebut juga perlu didukung berbagai unsur terkait seperti pemerintahan akademisi dan pelaku usaha sebagai fasilitator; dan

c. Penguatan peran masing-masing pihak dalam pembangunan desa terpadu inovatif dilakukan dengan membangun kerangka kebijakan yang tegas dari pemerintah pusat, pengawalan, monitoring dan evaluasi dari pemerintah provinsi dan pemerintah kabupaten serta komitmen segenap unsur desa. Akademisi secara kontinyu berhubungan dengan desa, dunia usaha menjalin kerjasama secara berkelanjutan dengan desa.

\section{DAFTAR PUSTAKA}

Abdurahman, Dudung. 2003. Pengantar Metode Penelitian. Yogyakarta: Kurnia Kalam Semesta.

Adisasmita, Raharjo. 2006. Membangun Desa Partisipasi. Yogyakarta: Graha Ilmu.

Dagun. Save M. 2006. Kamus Besar Ilmu Pengetahuan. Jakarta: Lembaga Pengkajian Kebudayaan Nusantara (LPKN).

Daldjoeni dan Suyitno. 2004. Perdesaan, Lingkungan dan Pembangunan. Bandung: PT. Alumni.

Dwipayanan, Ari AA. 2003. Desa Adat: Antara Otentisitas dan Demokrasi. Yogyakarta: Pustaka Pelajar.

Eko, Sutoro. 2003. Meletakkan Desa dalam Desentralisasi dan Demokrasi. Yogyakarta: Pustaka Pelajar. 
2004. Reformasi Politik dan Pemberdayaan Masyarakat. Yogyakarta: APMD Press.

2006. Pembaharuan Desa Secara Irawan, Tahir. 2003. Pembaharuan Pemerintah Desa. Yogyakarta: IRE Press.

Partisipatif. Yogyakarta: Pustaka Pelajar.

Leeuwis, Cees. 2009. Komunikasi Untuk Inovasi Perdesaan. Yogyakarta: Penerbit Kanisius.

Morissan. 2010. Teori Komunikasi Massa. Bogor: Ghalia Indonesia.

Mulyasa. 2007. Manajemen Berbasis Sekolah. Bandung: PT. Remaja Rosdakarya Offset.

Peraturan Pemerintah Nomor 72 Tahun 2005 tentang Desa.

Rustiadi, Ernan, Sunsun Saefulhakim, Dyah R Panuju. 2009. Perencanaan dan Pengembangan Wilayah. Jakarata: Yayasan Obor Indonesia.

Safi'i. 2009. Manajemen Pembangunan Daerah, Teori dan Aplikasi. Malang: Averroes Press

Santoso, Purwo. 2003. Menuju Tata Pemerintahan dan Pembangunan Desa dalam Sistem Pemerintahan Daerah: Tantangan Bagi DPRD. Yogyakarta: Pustaka Pelajar,. 2007. Prospek Pengembangan Desa. Bandung: Fokus Media.

Soetomo. 2006. Strategi-Strategi Pembangunan Masyarakat. Yogyakarta: Pustaka Pelajar.

Sukardi, Akhmad. 2009. Participatory Governance Dalam Pengelolaan Keuangan Daerah. Yogyakarta: Laks Bang Pressindo.

Suryabrata, Sumadi. 2006. Metodologi Penelitian, Jakarta: PT. Raja Grafindo Persada.

Tarigan, Robinson. 2008. Perencanaan Pembangunan Wilayah; Edisi Revisi. Jakarta: Bumi Aksara.

Undang-Undang Nomor 32 Tahun 2004 tentang Pemerintahan Daerah.

Wasistiono, Sadu. 2003. Kapita Selekta, Manajemen Pemerintahan Daerah. Bandung: Fokus Media.

Winarno, Budi. 2008. Gagalnya Organisasi Desa dalam Pembangunan di Indonesia. Yogyakarta:Tiara Wacana. 